\section{Separate education persists}

\section{Cape Town}

THE South African government has released Nelson Mandela, ended the ban on the African National Congress and allowed the return of political exiles, but it is still not prepared to deracialize its education system.

The Minster of (African) Education and Training, Stoffel van der Merwe, told a briefing for journalists last week that this would create "tremendous chaos," and would have a negative effect on both political stability and the economic system. Once the different education departments had reached a point approaching equality, he indicated, the separation of the various departments could be re-examined.

It is difficult to see just how the present government envisages this happening during its lifespan. In 1986 it embarked on ties in per capita expenditure on education between racial groups. But last year it ically unfeasable: current per capita spending on white schoolchildren is approximately five times that on African schoolchildren, and whites comprise only 10 per cent of the 9 million pupils in the country.

These discrepancies are no longer reflected so much by differences in standards between examining boards, which have narrowed in recent years, but by pupil:teacher ratios, teachers' qualifications and subjects offered. For example, only 30 per cent of African pupils study mathematics at any level, and in 1988 only 764 passed the subject in the higher grade, compared to approximately 12,000 whites.

Now van der Merwe says that money a ten-year programme to elimate dispariacknowledged that this goal was econom- released as a result of cuts in defence spending will be directed towards black education, and he hopes that this will be supplemented in future by funds likely to become available as a result of the possible relaxation of sanctions.

Although the figures will not be announced until the budget next month, it is suspected that these funds will be required simply to meet the demand for increased facilities: an estimated one million African children have no schools to go to and 300 new schools and 8,000 additional teachers are needed each year to met demand from the 250,000 African pupils entering the system. In contrast, the white school-going population is declining by 9,000 per annum, and there are currently 308,000 places open at white schools ( 26 per cent of places available). In addition, the government has closed 196 white schools over the past decade.

But they continue to refuse state schools the option of becoming nonracial, despite the fact that several leading ones have expressed a desire to do so.

In Port Elizabeth last week, 100,000 people marched on the offices of the Department of Education and Training to demand the opening of schools to all races. In this eastern Cape city, 3,000 African pupils were unable to be accomodated when the school term commenced last month. In response to this, local communities mustered up to 40 unemployed teachers in the city who were prepared to teach them at existing schools by adding an additional shift to the day's programme. The Department of Education and Training responded that it simply did not have the funds to pay their salaries.

Michael Chern

\section{Successful Japanese} launch

Tokyo

JAPAN's National Space Development Agency (NASDA) last week successfully launched a marine observation satellite (MOS-1b). The satellite will provide highresolution images of ocean currents, temperature and sediment distribution in the sea surface and of vegetation, snow cover and geological features on land. It will also collect information on cloud and

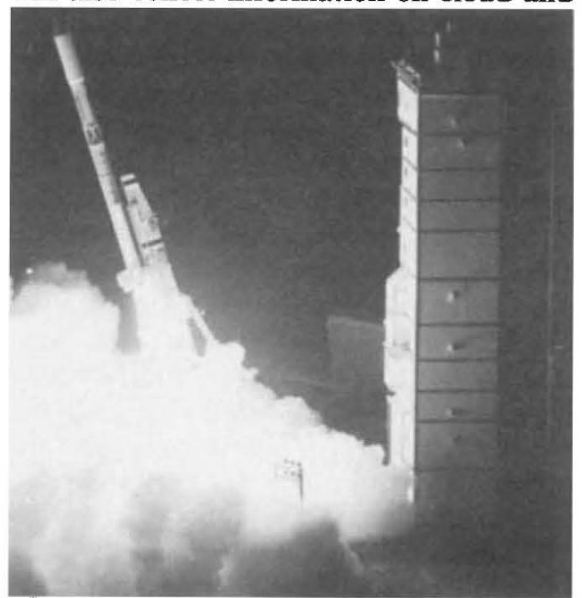

Japan's moon launch of a few weeks back.

water vapour distribution in the atmosphere. The Sun-synchronous orbit will allow the satellite to scan the whole surface of the Earth every 17 days.

The H-1 launch vehicle also deployed a small satellite for use by amateur radio operators and a Deployable Boom and Umbrella satellite which will repeatedly extend and retract a $95-\mathrm{cm}$ diameter umbrella to test out techniques for braking and altering the orbit of satellites.

David Swinbanks

INDIA

\section{Turning to turtles to clean Ganga \\ Bangalore}

CARnivorous turtles are to be released into the River Ganga in an effort to help reduce the effects of the age-old practice of throwing half-burnt human bodies into the river. A Rs2,920-million project to clean up the heavily polluted Ganga is already underway but has had difficulty finding solutions to the problem of floating corpses in the river.

"Since the problem of getting rid of dead flesh defied technical solutions, raising turtles semed a safer biological option", says a spokesman for the clean-up project. About 7,000 meat-eating turtles are being reared in a special farm and will be released into the river. The plan is considered essential because pious Hindus who regard the river as divine are thought unlikely to make much use of the 32 electric crematoriums being set up along the banks of the river. 